\title{
Homenagem ao Professor Saul Goldenberg
}

\section{Hélio Plapler}

Chefe da Disciplina de Técnica Operatória e Cirurgia Experimental do Departamento de Cirurgia da Universidade Federal de São Paulo.

Quando, em 1973, entrei pela primeira vez como aluno da Disciplina de Técnica Operatória e Cirurgia Experimental na então Escola Paulista de Medicina, fui recebido pelo novo Chefe da Disciplina, o Professor Saul Goldenberg.

A partir de então, seja como aluno, monitor e mais tarde como pós-graduando e como professor, acompanhei e participei do enorme avanço que a Disciplina conseguiu graças ao trabalho hercúleo deste homem que se mostrou incansável ante as dificuldades e disposto a alcançar níveis cada vez mais altos.

Difícil encontrar algo no campo da Educação em Cirurgia que não tenha sido criado ou desenvolvido pelo Professor Saul. Sua política de "portas abertas" sempre acolheu alunos de todas as partes do País, médicos e professores que foram injustiçados em outros setores, da universidade ou de fora dela, gente disposta a trabalhar e a desenvolver a pesquisa em cirurgia. Foi na Disciplina de Técnica Operatória e Cirurgia Experimental que alunos puderam tomar o primeiro contato com a pesquisa - embrião do futuro PIBIC além da disputada monitoria; foi ali também que teve início o Curso de Pós-Graduação em Técnica Operatória, modelo de desenvolvimento da pesquisa e da formação de pesquisadores de alto nível, pois vários de seus alunos são hoje nomes consagrados em suas instituições de origem. Foi aí que nasceu uma "apostila" contendo as teses produzidas neste curso, rodadas na gráfica da Escola, intitulada Acta Cirúrgica Brasileira. Me pergunto hoje: "- Aonde foi parar aquela apostila?" Bem, parece que se tornou a revista de referência na Cirurgia Experimental, indexada, reconhecida, tudo graças ao trabalho do Professor Saul.

Foi por este e outros motivos que os alunos (eternos) do Professor Saul resolveram homenageá-lo conferindo ao prédio da Disciplina de Técnica Operatória e Cirurgia Experimental da Escola Paulista de Medicina o seu nome. Em uma cerimônia singela, porém marcante, o nome do Professor Saul Goldenberg ficou definitivamente estampado sobre as portas que ele sempre manteve aberta a todos os que o procuraram.
É assim, Professor, que todos os alunos, hoje e sempre, continuarão a ser recebidos na Disciplina à qual o senhor tanto se dedicou. Serão recebidos pelo Professor Saul Goldenberg.

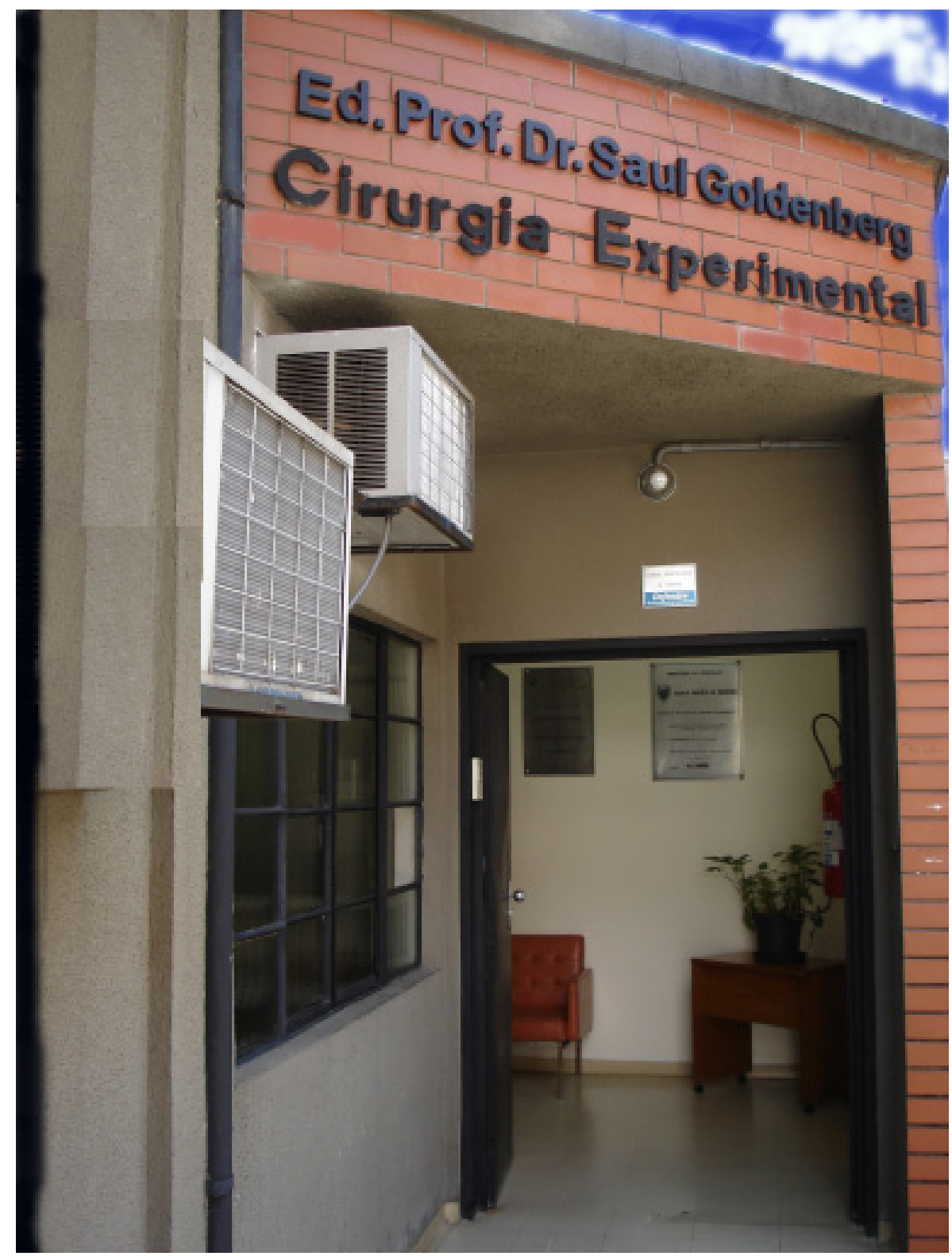

